\title{
DESAIN KEMASAN MINUMAN BUBUK SARI PALA MENGGUNAKAN METODE KANSEI ENGINEERING
}

\author{
Stevianus Titaley ${ }^{1}$; Ariviana L Kakerissa ${ }^{2}$; Alistya R. Tukuboya ${ }^{3}$; \\ E-mail: ${ }^{1}$ stevitita@gmail.com, ${ }^{2}$ vianakakerissa71@gmail.com \\ Jurusan Teknik Industri, Fakultas Teknik Universitas Pattimura Ambon
}

\begin{abstract}
ABSTRAK
Dalam memilih suatu produk dan memutuskan untuk membeli, konsumen akan selalu dipengaruhi oleh perasaannya. Oleh karena itu, hal ini sebaiknya dipertimbangkan oleh produsen pada saat merancang produk. Salah satu aspek penting dalam produk adalah kemasan.Tujuan dari penelitian ini adalah merancang kemasan dengan menentukan nilai-nilai kategori untuk mendapatkan output dari desain kemasan minuman bubuk sari pala. Metode yang digunakan adalah Kansei Engineering.Kansei Engineering dapat didefiniskan sebagai sebuah metodologi untuk menerjemahkan proses-proses psikologis manusia terhadap desain produk yang diinginkan, dengan cara mendefinisikan keinginan konsumen yang teridentifikasi melalui kata-kata kansei ke dalam desain produk. Analisa Conjoint digunakan untuk mendapatkan nilai hubungan antara desain elemen dan kansei word. Hasil dari penelitian ini adalah peneliti mendapatkan 7 pasang kansei word yang mewakili kata-kata yang tepat dengan mempertimbangkan produk yang ditawarkan. Berdasarkan hasil dari analisa Conjoint didapatkan tampilan desain yang terlihat sederhana, dari bahan plastik, dengan campuran warna hijau kuning, ilustrasi gambar buah pala dengan ukuran sedang.
\end{abstract}

Kata Kunci : Kansei Engineering, Kansei Word, Kemasan Minuman Bubuk, Citra/Image Konsumen

\section{PENDAHULUAN}

Produk merupakan suatu barang yang di tawarkan produsen dengan harus diperhatikan, diminta, dicari, dibeli, digunakan atau di konsumsi oleh seorang konsumen pasar sebagai pemenuhan kebutuhan hidup. Ada bermacam-macam produk yang dapat ditawarkan antara lain sebagai contoh bisa berupa barang fisik, jasa dan lain-lain. Produk yang ditawarkan bersifat sebagai suatu usaha, dimana dalam usaha tersebut produsen berkeinginan untuk mendapatkan keuntungan dari produk yang ditawarkan dan diminati oleh konsumen.

Pada usaha masyarakat yang memproduksi makanan atau minuman ringan tradisional harusnya dapat mengoptimalkan kualitas rasa dan desain kemasan sehingga dapat bersaing di pasaran dengan produk-produk lain. Tampilan kemasan menjadi faktor penarik konsumen yang dibutuhkan, karena penampilan serta bentuk variasi makanan dan minuman ringan tradisional akan bersaing dengan produk makanan pabrikan yang mempunyai kualitas rasa dan desain kemasan yang membuat konsumen tertarik untuk membelinya

Mendesain kemasan ini merupakan strategi yang sangat vital untuk mendukung peningkatan nilai jual produk, karena pada masa sekarang persaingan terus meningkat dan semakin ketat tetapi pola konsumsi masyarakat yang bergeser pada produk-produk cepat saji dan praktis.

Dengan penampilan produk yang kurang menarik pencapaian suatu penjualan tidak akan tercapai, dengan kemasan yang bagus maka citra produk pun tidak jauh akan mencapai tingkat keberhasilan. Penelitian mengembangan desain kemasan yang sesuai dengan keinginan konsumen untuk meningkatkan angka penjualan dengan kansei engineering. Penelitian ini diharapkan mampu memberikan kepuasan emosional pada konsumen dan produk mendapat nilai tambah dari konsumen. 


\section{KAJIAN TEORI \& METODE}

Dalam artikel yang disampaikan oleh Mu'alim dkk (2014) menjelaskan bahwa [1]. Pengemasan adalah kegiatan merancang dan memproduksi wadah atau bungkus sebagai sebuah produk, [2]. Pengemasan merupakan proses yang berkaitan dengan perancangan dan pembuatan wadah atau pembungkus untuk suatu produk. [3]. Kemasan dapat diartikan sebagai suatu benda yang berfungsi untuk melindungi, mengamankan produk tertentu yang berada di dalamnya serta dapat memberikan citra tertentu pula untuk membujuk penggunanya [4]. Secara fungsi wujudnya harus merupakan kemasan yang mudah di mengerti sebagai suatu yang mudah dibawa, melindungi dan mudah dibuka untuk benda maupun produk apapun. Yang terpenting, kemasan harus berhasil dalam uji kelayakan sebagai fungsi pengemas, dapatkah menjaga produknya secara keseluruhan, dapatkah menjaga untuk mengkondisikan produk tersebut dalam jangka waktu tertentu dan karena perpindahan tempat.

Ada tiga alasan utama untuk melakukan pembungkusan, yaitu: (1) Keamanan produk yang dipasarkan. Kemasan dapat melindungi produk dalam perjalanannya dari produsen ke konsumen. Produk-produk yang dikemas biasanya lebih bersih, menarik dan tahan terhadap kerusakan yang disebabkan oleh cuaca. (2) Membedakan dengan produk pesaing. Kemasan dapat melaksanakan fungsi pemasaran. Melalui kemasan identifikasi produk menjadi lebih efektif dan dengan sendirinya mencegah pertukaran oleh produk pesaing. Kemasan merupakan satusatunya cara perusahaan membedakan produknya. (3) Meningkatkan penjualan. Karena itu kemasan harus dibuat menarik dan unik, dengan demikian diharapkan dapat memikat dan menarik perhatian konsumen.

Kemasan yang baik dan akan digunakan semaksimal mungkin dalam pasar harus mempertimbangkan dan dapat menampilkan beberapa faktor, yaitu: (1) Faktor pengamanan. Kemasan harus melindungi produk terhadap berbagai kemungkinan yang dapat menjadi penyebab timbulnya kerusakan barang, misalnya: cuaca, sinar matahari, jatuh, tumpukan, kuman, serangga dan lain-lain. Contohnya, kemasan biskuit yang dapat ditutup kembali agar kerenyahannya tahan lama. (2) Faktor ekonomi. Perhitungan biaya produksi yang efektif termasuk pemilihan bahan, sehingga biaya tidak melebihi proporsi manfaatnya. Contohnya, produk-produk refill atau isi ulang, produk-produk susu atau makanan bayi dalam karton, dan lain-lain. (3) Faktor pendistribusian. Kemasan harus mudah didistribusikan dari pabrik ke distributor atau pengecer sampai ke tangan konsumen. Di tingkat distributor, kemudahan penyimpanan dan pemajangan perlu dipertimbangkan. Bentuk dan ukuran kemasan harus direncanakan dan dirancang sedemikian rupa sehingga tidak sampai menyulitkan peletakan di rak atau tempat pemajangan. (4) Faktor komunikasi. Sebagai media komunikasi kemasan menerangkan dan mencerminkan produk, citra merek, dan juga bagian dari produksi dengan pertimbangan mudah dilihat, dipahami dan diingat. Misalnya, karena bentuk kemasan yang aneh sehingga produk tidak dapat "diberdirikan", harus diletakkan pada posisi "tidur" sehingga ada tulisan yang tidak dapat terbaca dengan baik; maka fungsi kemasan sebagai media komunikasi sudah gagal. (5) Faktor ergonomi. Pertimbangan agar kemasan mudah dibawa atau dipegang, dibuka dan mudah diambil sangatlah penting. Pertimbangan ini selain mempengaruhi bentuk dari kemasan itu sendiri juga mempengaruhi kenyamanan pemakai produk atau konsumen. (6) Faktor estetika. Keindahan pada kemasan merupakan daya tarik visual yang mencakup pertimbangan penggunaan warna, bentuk, merek atau logo, ilustrasi, huruf, tata letak atau layout, dan maskot. Tujuannya adalah untuk mencapai mutu daya tarik visual secara optimal. (7). Faktor identitas. Secara keseluruhan kemasan harus berbeda dengan kemasan lain, memiliki identitas produk agar mudah dikenali dan dibedakan dengan produk-produk yang lain. (8) Faktor promosi. Kemasan mempunyai peranan penting dalam bidang promosi, dalam hal ini kemasan berfungsi sebagai silent sales person. Peningkatan kemasan dapat efektif untuk menarik perhatian konsumen-konsumen baru. (9) Faktor lingkungan. Kita hidup di dalam era industri dan masyarakat yang berpikiran kritis. Dalam situasi dan kondisi seperti ini, masalah lingkungan tidak dapat terlepas dari pantauan kita. Trend dalam masyarakat kita akhir-akhir ini yaitu kekhawatiran 
mengenai polusi, salah satunya pembuangan sampah. Salah satunya yang pernah menjadi topik hangat adalah styrofoam. Pada tahun 1990 organisasi-organisasi lingkungan hidup berhasil menekan perusahaan Mc Donalds untuk mendaur ulang kemasan-kemasan mereka. Sekarang ini banyak perusahaan yang menggunakan kemasankemasan yang ramah lingkungan (environmentally friendly), dapat didaur ulang (recyclable) atau dapat dipakai ulang (reusable).

Pada dasarnya kebutuhan emosional konsumen akan suatu produk layanan/jasa kian dominan. Kansei Engineering (KE) adalah metode untuk memastikan bahwa suatu produk atau jasa memenuhi tanggapan emosional yang diinginkan. Proses ini memungkinkan untuk memodelkan perasaan/emosi pelanggan dan kemudian menerjemahkannya ke dalam parameter desain. Dalam bahasa Jepang, kansei berarti emosi. Emosi yang dimaksud tidak hanya dari segi pikiran, namun meliputi penglihatan, pendengaran, perasaan,bau, rasa, serta kognisiakan terlibat secara simultan [5]. KE dianggap memiliki keunggulan terhadap metode lain yang serupa, karena metode ini memiliki kemampuan untuk menerjemahkan kebutuhan emosional konsumen kedalam parameter desain yang konkret melalui teknik-teknik tertentu. [6]

Prosedur standar dalam pendekatan KE, terdiri dari 4 langkah yaitu: (1). Identifikasi suatu produk akan kebutuhan konsumen dari segi images dan ergonomis berdasarkan perasaan psikologis. (2) Ekstraksi parameter produk agar dapat memuaskan calon konsumen. (3). Pengembangan kansei engineering untuk mendapatkan teknologi ergonomis.

Melakukan penyesuaian desain suatu produk berdasarkan preferensi konsumen dan kelompok sosial.

Untuk mendesain suatu produk, Kansei Engineering System (KES) memerlukan bantuan sistem yang mendukung perasaan dan citra (image) konsumen ke dalam elemen-elemen desain fisik. [7]. Gambar 1 menunjukkan diagram proses KES.

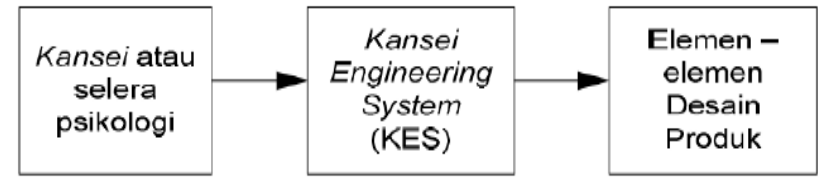

Gambar.1. Diagram Proses KES

KES pada dasarnya memiliki 4 basis data dan sebuah mesin inference dalam strukturnya. 4 basis data yaitu: (1) Basis Data Kansei (Kansei Word Database). Kansei Word yang digunakan dalam domain produk baru dikumpulkan dari majalahmajalah sistem yang berkaitan. Kansei Word ini kebanyakan dievaluasi melalui metode Semantic Differential dan kemudian dianalisis dengan metode statistik, seperti analisis sistem. Hasil dari analisis sistem memberi saran akan petunjuk Kansei Word yang akan digunakan, yang akan menjadi sumber basis data Kansei Word yang dibangun ke dalam sistem. (2) Basis Data Citra (Image Database). Hasil pengujian dengan Semantic differential merupakan analisis kedua dalam teori Kuantitatif Hayashi tipe 1. Melalui analisis ini, kita bisa mendapatkan daftar hubungan antara kata kansei dan elemen-elemen desain. Setelah itu kita dapat mengidentifikasi kata kansei, yang memberikan item-item tertentu desain detail. Sebagai contoh, jika konsumen menginginkan sesuatu yang indah, kata kansei ini merespon dengan beberapa desain detail dalam sistem. Data ini membangun basis data citra dan basis peraturan. (3) Basis Pengetahuan (Knowledge Base). Basis pengetahuan terdiri dari aturan-aturan yang dibutuhkan untuk memutuskan tingkat korelasi antara item-item rincian desain dengan Kansei Word. Beberapa aturan dihasilkan dari perhitungan teori kuantifikasi dan beberapa dari prinsip-prinsip kondisi warna, panduan desain kasar dan masih banyak lagi. Gambar 2. menunjukkan struktur Kansei Engineering System. 


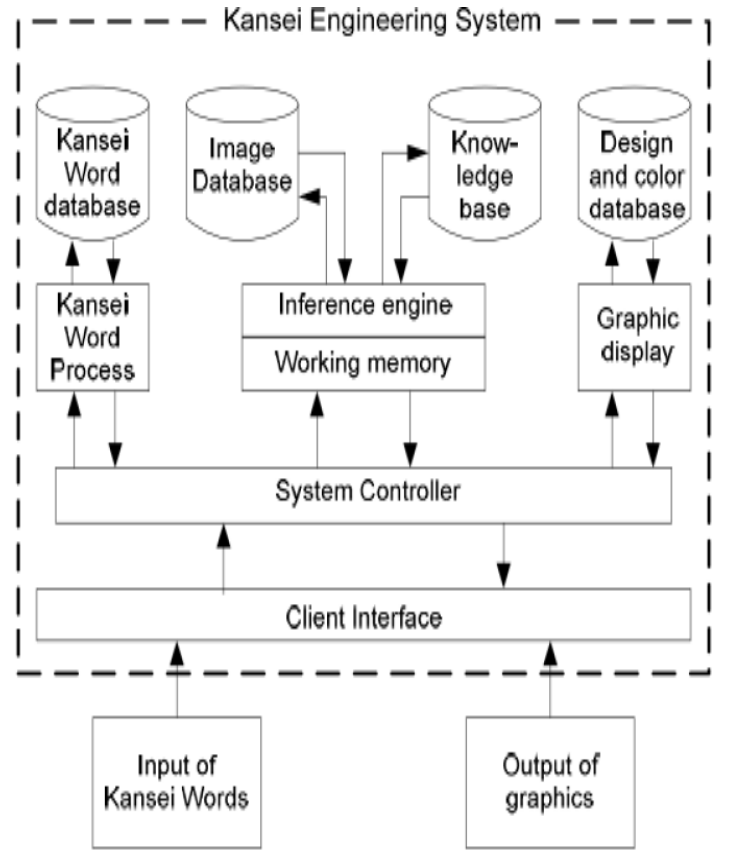

Gambar 2.Struktur Sistem KES

(4) Basis Data Desain dan Warna (Design and Color Database). Detil-detil desain diterapkan pada basis data desain bentuk dan basis data pengecatan warna secara terpisah. Semua detildetil desain terdiri dari desain aspek yang berhubungan sebagai bentuk total dengan masingmasing Kansei Word. Basis data warna terdiri dari warna yang beragam yang juga dihubungkan pada Kansei Word. Desain gabungan dengan bentuk dan ukuran ini di kutip dengan sistem inferensi yang spesifik berdasarkan basis peraturan dan kemudian ditampilkan dalam grafik dilayar.

Metode analisis data yang digunakan dalam penelitian ini dilakukan secara sistematis untuk menjawab tujuan penelitian. Metode yang digunakan akan bervariasi, antara lain :

1. Uji Validitas dan Reliabilitas

Validitas dan reliabilitas dalam penelitian ini menggunakan satu istilah metode. Pengukuran penelitian ini akan menggunakan software statistic, SPSS versi 16.0, untuk menentukan uji validitas dan reliabilitas. Penelitian ini menggunakan 0.05 tingkat ke-signifikan dan derajat kebebasan (n-2), dimana $n$ adalah jumlah kuesioner. a. Validitas

Tingkat kesignifikan

$\alpha=0,05 ; \mathrm{df}=\mathrm{n}-2$, dimana $\alpha$ merupakan toleransi kesalahan dan $\mathrm{n}$ merupakan banyaknya kuesioner yang telah diuji. Dimana nilai $r$ tabelnya adalah $\mathrm{df}=100-2=$ 98, sehingga nilai $r$ tabel yaitu sebesar 0,196 . Jika $r$ hitung $\geq r$ tabel (Valid)

Jika $r$ hitung $<\mathrm{r}$ tabel (Tidak Valid)

b. Reliabilitas

Tingkat kesignifikan

$\alpha=0,05 ; \mathrm{df}=\mathrm{n}-2=100-2=98 ; \mathrm{r}$ tabel $=$ 0,196 .

Jika $r$ alpha $\geq r$ tabel (Reliable)

Jika $r$ alpha $<\mathrm{r}$ tabel (Tidak Reliable)

2. Analisa Faktor

Setelah melakukan uji validitas dan reliabilitas, maka selanjutnya melakukan evaluasi terhadap ketetapan kata-kata yang ada. Analisa faktor digunakan untuk mengetahui kansei word yang dominan dari beberapa variable kata yang akan dipilih. Dalam analisa faktor, pengolahan datanya menggunakan SPSS. Menu yang digunakan di analisa faktor adalah analisa pengurangan data dan kemudian faktor pilihan. Langkah-langkah pengolahan data dengan analisa faktor adalah sebagai berikut :

a. Membangun Matrik Korelasi

b. Tes nilai KMO (Kaiser-Meyer-Olkin) dan tes Bartless

Nilai KMO $>0,5$ (Layak)

Nilai KMO $<0,5$ (Layak)

MSA $==$ Variable dapat dipresiksi tanpa

$$
1 \text { kesalahan dari variable lain. }
$$

MSA $>$ Variable masih dapat 0,5 diprediksi tanpa kesalahan dari variable lain dan dapat dianalisa lebih lanjut.

MSA $<=$ Variable tidak dapat 0,5 diprediksi tanpa kesalahan dari variable lain dan tidak dapat dianalisa lebih jauh, atau harus dipindahkan keluar dari variable-variabel lain.

c. Analisa Matrik Anti Image

Nilai MSA (Measure of Sampling Adequacy) bervariasi antara 0 sampai 1 , dengan kriteria : 


\section{Analisa Conjoint}

Setelah dilakukan analisa faktor, maka selanjutnya menentukan tingkat kepentingan relative atribut-atribut pada proses pemilihan yang dilakukan oleh konsumen. Proses dasar analisa Conjoint adalah sebagai berikut :

1) Menentukan faktor dan level sebagai atribut spesifik sebuah objek.

2) Mendesain stimuli (sampel).

3) Mengumpulkan pendapat responden.

4) Melakukan proses Conjoint dengan memasukkan sejumlah data untuk mengetahui dan memprediksi keinginan/ preferensi responden terhadap produk yang diteliti.

Menentukan ketetapan prediksi (predictive accurancy) dari hasil analisis Conjoint.Populasi pada penelitian ini semua konsumen minuman ringan berbentuk bubuk pala yang akan dirancang pengemasannya. Cara yang digunakan untuk pengambilan sampel adalah dengan cara incidental sampling/accidental sampling, yaitu teknik penentuan sampel berdasarkan kebetulan (incidental) bertemu dengan konsumen kacang kedelai. Jumlah sampel ditentukan sebanyak 100 responden.

\section{HASIL DAN PEMBAHASAN}

\section{Penentuan Kansei Word}

Pengumpulan kansei word melalui dua sumber yaitu penyebaran kuesioner terbuka dan studi literature. Dari kuesioner awal didapatkan kansei word sebanyak 25 Dan 9 kansei word dari literature sehingga total kansei word sebanyak 34 kansei word. Kemudian kata ini diberikan kepada responden yang akan diteliti. Dari hasil pemilihan kansei word didapatkan 15 kansei word yang relevan dan sesuai dengan keinginan konsumen.
Tabel.3. Pengumpulan Kata Kansei

\begin{tabular}{|c|c|}
\hline No & Kansei word \\
\hline 1 & Menarik \\
\hline 2 & Awet \\
\hline 3 & Bersih \\
\hline 4 & Berwarna \\
\hline 5 & Memiliki ciri khas \\
\hline 6 & Efisien \\
\hline 7 & Mudah dibuka \\
\hline 8 & Artistik \\
\hline 9 & Inovatif \\
\hline 10 & Komplek \\
\hline 11 & Modern \\
\hline 12 & Informatif \\
\hline 13 & Mudah dibawa \\
\hline 14 & Unik \\
\hline 15 & Ramah lingkungan \\
\hline
\end{tabular}

Kata-kata kansei atau bisa disebut Kansei Word diperoleh dari hasil wawancara terhadap responden, Kansei Word di kumpulkan dari responden yang bersifat psikologis atau kesan responden terhadap kemasan produk kacang kedelai tersebut [10], sehingga hasil dari Kansei Word dapat dipresentasikan pada desain kemasan kacang kedelai yang diinginkan oleh para konsumen. Kansei Word yang diperoleh dengan cara wawancara dari responden akan diidentifikasi, dimana peneliti akan pengelompokan kata tersebut yang bermakna sama. Selanjutnya kata Kansei Word dieliminasi dengan memilih jumlah kata kansei terbanyak berdasarkan pemilihan responden. Namun tahap eliminasi ini produsen berhak memasukan kata kansei yang lebih sedikit dipilih responden yang dirasa sesuai untuk perancangan desain kemasan bubuk pala. Elemen desain pada penelitian ini yaitu kemasan bubuk pala. Elemen desain diperoleh dari hasil pemikiran peneliti dan produsen yang berpedoman dengan Kansei Word. Elemen desain berperan untuk mempresentasikan sebuah produk sehingga dapat dinilai oleh para konsumen dan sekaligus menjadi daya tarik untuk konsumen.

\section{Identifikasi Susunan Kata Kansei}

Identifikasi kansei susunan kata kansei, pada identifikasi ada 2 tahap yaitu dengan cara mengelompokkan kata kansei yang bermakna sama dan mengeliminasi kata kansei. 


\section{Penetapan Elemen Desain}

Berdasarkan pendekatan elemen desain dari hasil perhitungan dengan analisa conjoint, didapatkan 7 elemen desain. Dari 7 Elemen desain yang akan dipilih dan dirancang yaitu elemen desain yang terbentuk dari banyaknya nilai-nilai terbesar masing-masing kategori yang sering muncul. Dari 7 (tujuh) elemen desain, nilai terbesar masingmasing kategori yang sering muncul dan menjadi konsep rancangan produk adalah :

1. Tampilan (Sederhana)

Tampilan pada kemasan minuman bubuk sari pala terlihat sederhana.

2. Bahan (Plastik)

Bahan yang digunakan untuk kemasan minuman bubuk sari pala adalah jenis kemasan plastik polypropylene.

3. Warna (Hijau kuning)

Warna yang diinginkan pada tampilan kemasan yaitu campuran warna hijau kuning. Dimana warna hijau yang digunakan yaitu jenis warna RGB Green dan warna kuning yaitu RGB Yellow.

4. Ilustrasi (Buah Pala)

Ilustrasi atau gambar yang di tampilkan untuk ciri khas produk adalah gambar buah pala.

5. Ukuran (Sedang)

Kemasan minuman bubuk sari pala berukuran $7,5 \times 9 \mathrm{~cm}$ dengan berat bersih produk 14gram. Desain produk yang dipilih dan dirancang memiliki spesifikasi seperti yang diinginkan responden.

Rancangan kemasan minuman ringan bubuk sari pala yang didesain seperti pada gambar $1 \& 2$ dibawah ini:

\section{DATA TEKNIS}

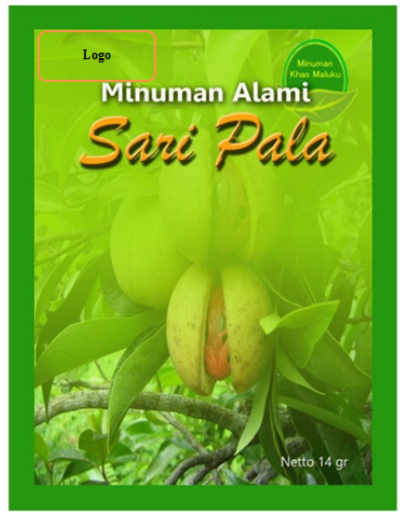

Gambar 1. Desain Kemasan Bubuk Pala (Tampak Depan)

\section{Tampak Depan}

a. Nama Produk : Minuman Alami Sari Pala

b. Ilustrasi : Buah Pala Matang

c. Warna : Hijau Kuning

d. Bentuk Kemasan : Kotak/segiempat

e. Ukuran : - Lebar 7,5 cm

- Panjang $9 \mathrm{~cm}$

f. Warna : Hijau Kuning

g. Bahan Kemasan : Plastik Polypropylane

h. Logo : Logo Halal (MUI)

i. Berat Netto : 14 gram

\section{2) Tampak Belakang}

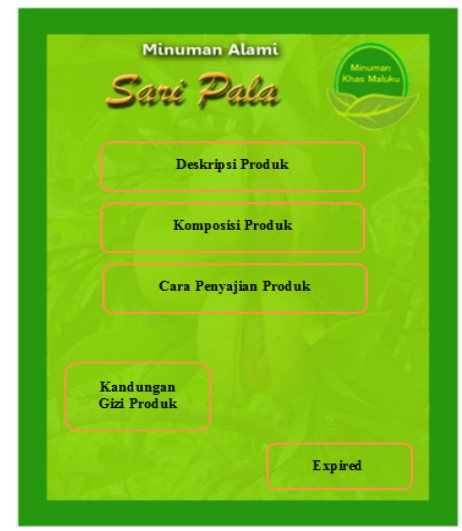

Gambar 2. Desain Kemasan Bubuk Pala (Tampak belakang) 


\section{Tampak Belakang}

a. Nama Produk : Minuman Alami Sari Pala

b. Ilustrasi : Buah Pala Matang

c. Warna : Hijau Kuning

d. Bentuk Kemasan : Kotak/segiempat

e. Ukuran : - Lebar $7,5 \mathrm{~cm}$ - Panjang $9 \mathrm{~cm}$

f. Warna : Hijau Kuning

g. Deskripsi Produk :

- Komposisi Produk

- Cara Penyajian Produk

- Kandungan Gizi

- Expired Date Produk

\section{KESIMPULAN}

Berdasarkan hasil penelitian dan pembahasan, dapat diperoleh kesimpulan sebagai berikut:

1. Citra atau image konsumen berdasarkan analisis Kansei Word didapat 7 (tujuh) kansei word yang melliputi diantaranya yaitu menarik, bersih, berwarna, memiliki ciri khas, efisien, mudah dibuka dan kompleks.

2. Terdapat 8 sampel yang didapat dari 12 kategori berdasarkan 5 atribut yang ada sebagai pengujian Semantic Differential II. Dengan menggunakan analisa Conjoint, didapatkan spesifikasi keinginan konsumen terhadap desain kemasan minuman bubuk sari pala. Spesifikasi yang didapatkan adalah tampilan desain kemasan yang terlihat sederhana, dari bahan plastik sachet polypropylene, dengan warna campuran hijau dan kuning, ilustrasi gambar buah pala dengan ukuran sedang yaitu $7,5 \times 9 \mathrm{~cm}$.

\section{DAFTAR PUSTAKA}

Hahury Hendri Dony, (2016), Fenomena SosialEkonomi Petani Pala di Negeri Booi, Pulau Saparua. Dokumen Progress Report Disertasi Program Doktor Universitas Kristen Satya Wacana, Salatiga.

Julianti Sri (2014), The Art of Packaging: Mengenal Metode, Teknik dan Strategi Pengemasan Produk untuk Branding dengan Hasil Maksimal, Gramedia, Jakarta.

Klimchuk, Marianne Rosner dan Krasovec, Sandra A. (2007), Desain Kemasan: Perencanaan Merek Produk yang Berhasil Mulai dari Konsep sampai Penjualan, Erlangga, Jakarta.

Kotler Philip \& Armstong Garry (2006), Principles of Marketing, $11^{\text {th }}$ Edition, New Jersey Prentice Hall, Pearson education, Inc., Upper Saddle River, New Jersey.

Lestari Dwi Arum Sri (2013), Redesain Kemasan Produk Makanan Ringan Aneka Gorengan Super $2 R$, Tugas Akhir, Fakultas Bahasa dan Seni, Universitas Negeri Semarang, 2013.

Nagamachi (1995), Kansei Engineering : A New Ergonomic Consumer Oriented Technology for Product Development, International Journal of Industrial Ergonomics, Vol 15, Hal 3-11, Japan.

Wirya, Iwan (1999), Kemasan Yang Menjual, PT. Gramedia Pustaka Utama, Jakarta 